УДК 001.8:[005.934-027.543:338.439.4]

\author{
Ощепков О.П. \\ кандидат економічних наук, доцент \\ кафедра обліку та аудиту \\ E-mail:motored@yandex.ru \\ Магденко C.0. \\ асистент \\ кафедра економіки промисловості \\ E-mail: maglana@meta.ua \\ Одеська національна академія харчових технологій \\ вул. Канатна, 112, м. Одеса, Україна, 65039
}

\title{
МЕТОДОЛОГІЧНІ ПИТАННЯ ДОСЛІДЖЕННЯ ПРОДОВОЛЬЧОЇ БЕЗПЕКИ В МЕЖАХ НАЦІОНАЛЬНОЇ БЕЗПЕКИ КРАЇНИ
}

\begin{abstract}
У роботі розглядаються методологічні питання дослідження продовольчої безпеки в межах загальної національної безпеки країни як системи, яка характеризується наявністю елементів, структури та зв'язків, функціонування і розвиток якої здійснюється на основі організаційно-економічного механізму погодження і реалізації економічних інтересів всіх суб'єктів діяльності в межах агропродовольчого комплексу і окремого підприємства.

Ключові слова: продовольча безпека, національна безпека, організаційно-економічний механізм, доходи, економічний інтерес.
\end{abstract}

Постановка проблеми та її зв'язок 3 важливими науковими та практичними завданнями. В умовах інтеграції та глобалізації економічних і соціальних процесів для кожної держави стає питання забезпечення системи національної безпеки. В межах національної безпеки країни особливе місце займає продовольча безпека, яка є умовою забезпечення життєдіяльності суспільства на всіх його рівнях: держави, регіону, міста, домашнього господарства та окремої людини. Інтереси людини повинні бути на першому місці, тільки та людина, яка має достатню кількість продовольства, а не голодна, здатна займатись наукою, культурою, відтворювати себе на найвищому рівні і може приймати адекватні рішення 3 управління соціально-економічними процесами в суспільстві. Продовольча безпека - це кількісна і якісна характеристика харчування людини, яка забезпечує нормальну його життєдіяльність.

Однак зараз ця проблема, форми прояви якої мають різноманітний характер, не вирішена, і питання забезпечення продовольчими ресурсами залишаються актуальними для багатьох країн світу, в тому числі й для України. Визначити форми та причини продовольчої безпеки на всіх рівнях функціонування суспільства та розробити шляхи подолання цього явища для країни стає головним завданням для уряду і всіх господарських структур агропродовольчого комплексу (АПК).

Аналіз останніх публікацій по проблемі. Значний вклад у дослідження питань продовольчої безпеки в межах національної безпеки та розвитку агропромислово- го комплексу внесено в працях Л. Абалкіна, О.Г. Білоус, I.I. Лукінова, А.О. Заїчковського, І.Г. Кириченко, А. Ревенко, П.Т. Саблука, В.В. Юрчишина та інших. Особливо ці питання загострились в кінці ХХ століття в зв'язку 3 загальною економічною кризою, високим рівнем інфляції та низьким рівнем купівельної спроможності населення, особливо в країнах пострадянського періоду. Використовуючи загальні тенденції розвитку АПК в умовах глобалізації, вступу до СОТ, Програми Свроінтеграції, для вирішення питань з продовольчої безпеки в межах національної безпеки були прийняті Закон України «Про національну безпеку України» і Закон України «Про продовольчу безпеку України», в яких наведено загальна характеристика та складові національної й продовольчої безпеки. Подальший розвиток поглядів на стан продовольчої безпеки відбувається в працях вітчизняних науковців Берегового В.К., Басюркиної Н.Й., Клочко В.М, Миленко В.3., Павлова О.І., Стройко Т.В., Ткачук Т.I., зарубіжних авторів Акмарал Темірової, Буженко О.А., Лі Чунюй та інших. Але більшість авторів розглядає окремі аспекти продовольчої безпеки: якісні, соціальні, економічні, техніко-технологічні, екологічні, регіональні і т.п. Разом $з$ тим, комплексного підходу до рішення цієї проблеми в повному обсязі не досліджено.

Формулювання цілей дослідження. Розробити алгоритм дослідження питань забезпечення продовольчої безпеки як складової національної безпеки країни, показати взаємозв'язок усіх елементів агропродоволь- 
чого комплексу (АПК) країни через організаційноекономічний механізм його функціонування та розвитку.

Виклад основних результатів та їх обгрунтування. Значна частина вчених розглядає окремі сторони складової продовольчої безпеки, на що вказують учасники науково-практичної конференції «Стратегія економічного розвитку харчової промисловості та забезпечення продовольчої безпеки країни» [15 ]. Разом 3 тим, всі фактори і причини продовольчої безпеки країни взаємопов'язані між собою і доповнюють один одного, тому треба підходити до дослідження даної проблеми як до системи, яку характеризують елементи, структура i організація зв'язків.
Досліджуючи продовольчу безпеку в межах загальної національної безпеки країни, необхідно враховувати всі інші складові національної безпеки країни, які тим чи іншим способом взаємопов'язані й взаємообумовлені та впливають на стан продовольчої безпеки. До таких елементів належать: військова безпека, економічна безпека, фінансова безпека, техніко-технологічна безпека, інформаційна безпека, екологічна безпека, демографічна безпека [6 ].

Взаємозв'язок і взаємообумовленість між елементами національної безпеки країни схематично представлено на рисунку 1.

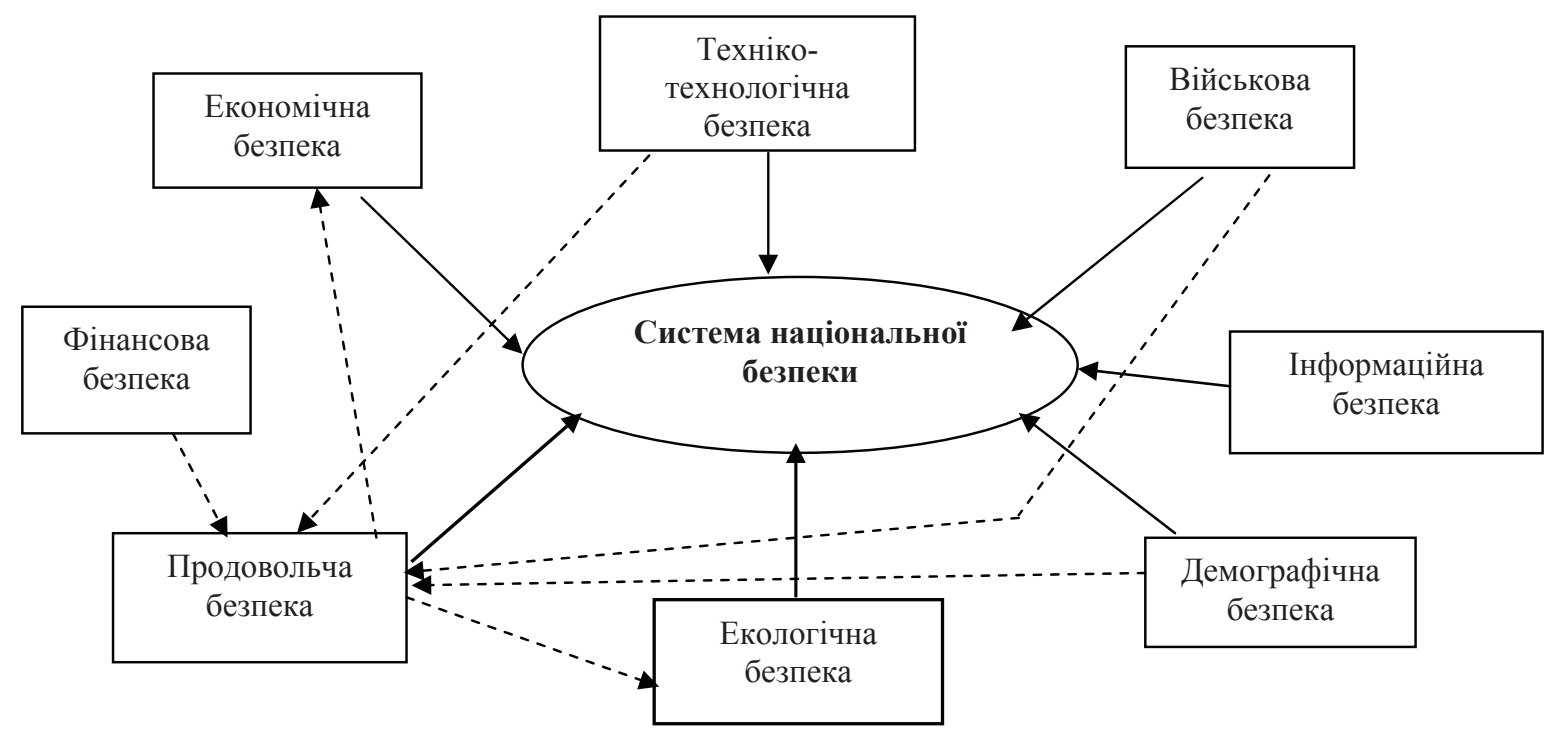

Рис. 1. Продовольча безпека в системі національної безпеки

Схема взаємозв'язку елементів національної безпеки показує, що продовольча безпека також впливає на економічну і фінансову безпеку та демографічну безпеку. Цей взаємозв'язок здійснюється тому, що від результатів діяльності АПК залежать обсяг ВВП і наповнення державного бюджету країни. Демографічна безпека обумовлена якістю і культурою харчування, що впливає на стан здоров'я населення, його продуктивність, тривалість життя i, навпаки, все це буде впливати на виробництво продуктів харчування.

Існують різні підходи до наявності продовольчої безпеки, так Береговой В.К. вважає, що «продовольчу безпеку можна визначати як стан захищеності населення країни від недостатнього харчування, а тим більш від голоду та наявність у держави для цього можливостей» $[4$, c.73]. Але такий підхід не передбачає раціонального повноцінного харчування, яке потрібне населенню для нормальної життєдіяльності. Тому треба підходити сис- темно до розгляду цієї проблеми. Значення системного підходу при дослідженні соціально-економічних питань акцентується в статті С. Афонцева [2]. Системність підходу до розгляду продовольчої безпеки країни дозволяє структурні елементи формувати за окремими принципами взаємозв' язків, що буде надавати стійкість та стабільність їі економічному розвитку.

Для системного розгляду підходів до питань продовольчої безпеки нами пропонується послідовність дослідження проблем та шляхів їх вирішення, яка наведена на рисунку 2.

Послідовність дослідження: визначення суті продовольчої безпеки, причин, факторів, шляхів вирішення питань та фінансування визначених напрямків рішення проблеми продовольчої безпеки.

Перший крок полягає в визначенні суті продовольчої безпеки, яка існує зараз в країні (фізіологічний голод, часткове недоїдання, або тільки нераціональне харчуван- 
ня) в розрізі регіонів та груп населення. Характеристику продовольчої безпеки наведено в Законі України «Про продовольчу безпеку України» [7]. Перший вид продовольчої безпеки присутній в східних областях Україні, де здійснюються бойові дії, в зв'язку з неможливістю своєчасно здійснювати доставку продуктів харчування. Часткове недоїдання існує серед більшості пенсіонерів, що складає третю частину населення країни. Нераціональне харчування також характерно для більшості населення країни, що пов'язано з низькою культурою харчування, низькою купівельною спроможністю населення та традиціями харчування.

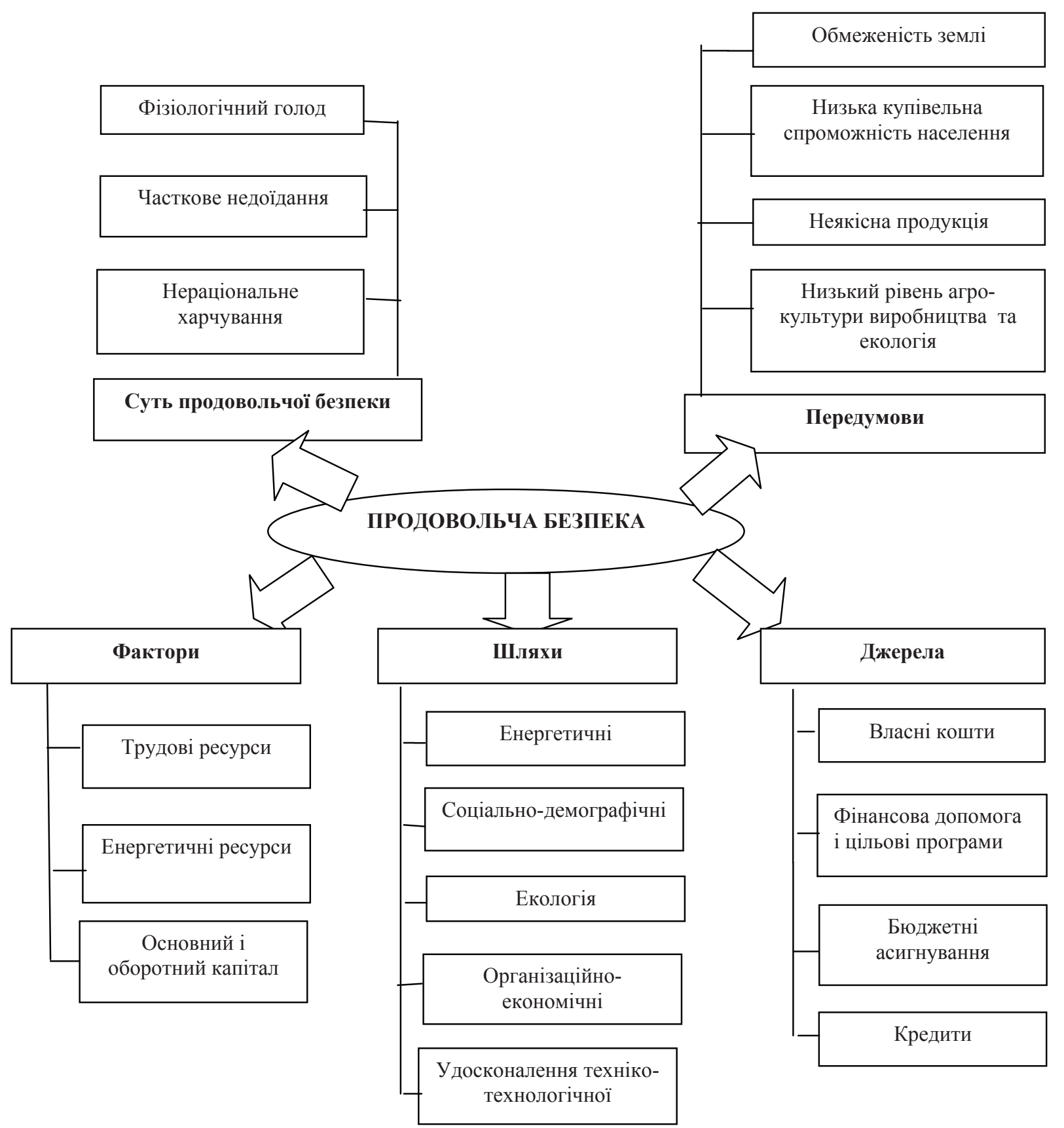

Рис. 2. Методологічні підходи до розгляду питання з продовольчої безпеки
Другий крок - це визначення причин продовольчої безпеки: обмеженість якісних земель, якість продуктів харчування, низький рівень доходів, екологічне забруднення. Дискусійним залишається питання обмеження землі. Але, реально, фізичний ï обсяг зменшується за рахунок будівництва житлових і промислових об'єктів, інфраструктури.

Частіше будівництво здійснюється на кращих землях, чорноземах. Розглядаючи теорію диференціальної ренти в аграрних відносинах, К. Маркс розділив землі за родючістю і місцем знаходження на найкращі, середні і найгірші [10, с.202-203]. Для середніх та найгірших зе- 
мель треба вкладати більше коштів для отримання продукції тієї ж кількості, як і на найкращих землях. Разом 3 тим, у світі проявляється дія теорії Мальтуса про «закон народонаселення», який стверджував, що населення збільшується в геометричної прогресії, а виробництво продуктів харчування - в арифметичній прогресії, яку свого часу критикував К. Маркс [11, с.465]. Дійсно, в світі відбувається демографічний вибух (Китай, Індія, країни Африки та інші), а продуктивні сили неспроможні в повному обсязі забезпечити все населення світу продуктами харчування. На це впливають кризові ситуації, природні катаклізми і неефективність використання продуктивних сил у сільському господарстві, що також характерне для розвитку сільського господарства в Україні.

Питання якості харчування залежить не тільки від громадянина, але й від виробника: які ним використовуються сировина, технології переробки та зберігання продукції, які терміни постачання споживачам. Разом все це впливає на стан здоров'я нації, іiі продуктивність, тривалість життя. Зараз багато авторів підкреслюють необхідність якості харчування шляхом розширення асортименту продуктів, збільшення виробництва за допомогою державної підтримки з використанням інноваційних технологій, в тому числі генної інженерії для виробництва генномодифікованої продукції. Але, як підкреслюють В.В. Немченко, А.В. Немченко, інноваційні технології виробництва продукції харчування повинні забезпечувати наявність усіх складових повноцінного харчування: жирів, білків, вуглеводів, макро- і мікроелементів, амінокислот [13].

Неможливість задовольняти потреби більшої частини населення України в раціональному харчуванні визначається за рахунок наступних факторів: великій рівень диференціації доходів, низький рівень мінімальної заробітної плати і прожиткового мінімуму, які розраховані тільки на мінімальне фізіологічне задоволення харчуванням без задоволення соціальних потреб. Низька платоспроможність населення негативно впливає на розвиток виробництва.

Екологічне забруднення навколишнього середовища пов'язане з використанням хімічних добрів, техногенних факторів, хімічних відходів та викиду різних шкідливих речовин до повітря.

Наступний крок - це визначення факторів, від яких залежить виробництво продуктів харчування: наявності оборотних коштів, стану основних засобів, кваліфікованої робочої сили, енергетичних ресурсів. Практично всі країни пострадянського періоду мають однакові проблеми: застаріла техніка, на селі не має кваліфікованих робітників, недостатність власних оборотних коштів, неможливість їх поповнення в зв'язку з дорогими кредитами.
Після визнання факторів, від яких залежить рішення продовольчої безпеки, треба розглядати шляхи рішення цієї проблеми. Починати треба 3 техніко-технологічного оновлення процесу виробництва у сільському господарстві по всіх його секторах (рослинництва, тваринництва, садівництва), соціально-економічного розвитку сільського населення, створення привабливих умов сільськогосподарської праці, зміни іiі умов і характеру на новій техніко-технологічній базі, комплексної механізації i автоматизації технологічних процесів, особливо в галузі тваринництва. Для цього потрібно також енергетичне забезпечення (паливо, електроенергія, мастила тощо). Замінити хімічні добрива, які шкодують навколишньому середовищу і залишаються в овочах і фруктах, на органічні добрива за рахунок збільшення чисельності тварин. Рішення демографічної проблеми на селі може бути тільки при створенні відповідних сучасних умов життєдіяльності (умов і характеру праці, розвитку соціальної сфери).

Одночасно треба створити новий організаційноекономічний механізм взаємодії суб'єктів діяльності АПК та взаємовідносин між державою і господарствами, господарствами та місцевою владою, який повинен відображати інтереси кожного з них, погоджувати і реалізовувати їх на всіх рівнях. На необхідність створення нового організаційно-економічного механізму забезпечення продовольчої безпеки вказує Басюркіна Н.Й. [3]. Ранжирування рішень продовольчої безпеки як складової національної безпеки на різних рівнях (світове співтовариство, держава, регіон, населення) шляхом системи постачання продуктів харчування від виробника до споживача розглядається в роботі Козак К.Б. [8, с.9].

Сутність організаційно-економічного механізму функціонування і розвитку полягає в об’єднанні факторів організації виробництва і праці, їх впливу на кінцеві результати діяльності, а також формування і розподілу доходу з метою погодження і реалізації інтересів суб'єктів діяльності.

Схему організаційно-економічного механізму функціонування підприємств АПК і окремого підприємства запропоновано на рис. 3 .

Надважливим кроком є визначення джерел фінансування реалізації запропонованих шляхів забезпечення продовольчої безпеки: власний капітал (нерозподілений прибуток, внески засновників, амортизація); кредити за рахунок високих відсотків розміри їх для більшості підприємств обмежені; державний і місцеві бюджети - в місцевих бюджетах, як правило, для цього коштів не має, iз державного бюджету кошти виділяють не системно і використовуються вони не ефективно за рахунок корупційних схем; фінансова допомога і цільові програми за- 


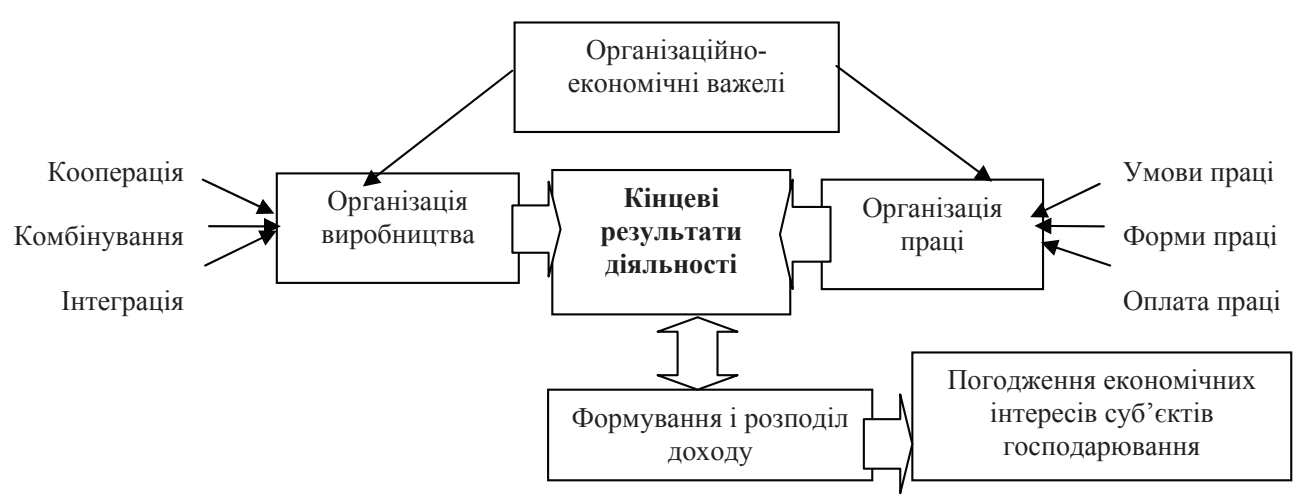

Рис. 3. Організаційно-економічний механізм функціонування агропромислового підприємства

рубіжних інвесторів - суми їх незначні в зв'язку з невизначеністю соціально-політичного стану в країні.

Використовуючи зарубіжний досвід і особливості соціально-економічного стану України необхідно системно наповнювати кожен елемент організаційноекономічного механізму відповідним змістом.

Механізм реалізації глобальної продовольчої безпеки, досвід державного регулювання аграрного сектору досліджено в роботі Лі Чунюй, в якої наведено приклади від Австралії до Європи, США і Канади підтримки і регулювання розвитку АПК шляхом дотацій від 50\% до 80\%, цінове регулювання на виробничі ресурси і вироблену продукцію, кредитне регулювання, державні закупівлі, антимонопольне регулювання, заборона на імпорт продукції, яка може вироблятись в країні з метою підтримки вітчизняного виробника та ін. [9]. Особливий досвід регулювання впливу на розвиток сільського господарства в Китаї. Одним із основних напрямів є регулювання цін через механізм «двоступеневої системи цін». Ціни, регульовані державою і ціни не регульовані, але гарантовані державою, в тому числі при використанні ф’ючерсних цін. Тобто, нерегульовані ціни формує ринок, але держава контролює стихійність цін. Значне місце займає створення страхових і резервних запасів [5].

Для формування моделі організаційно-економічного механізму забезпечення продовольчої безпеки України може бути використаний досвід щодо створення моделі економічної безпеки Республіки Казахстан, яка розглядається в межах національної безпеки з виділенням основних аспектів: суб'єкти, об'єкти, нормативно-правова база, загроза і показники для оцінки економічної безпеки країни [1].

Відповідно Стратегії ЄС «Свропа 2020» в Республіці Сербія для подолання продовольчої безпеки розроблена програма зниження рівня бідності. Це - розвиток місцевого самоврядування, децентралізація бюджетів і децентралізація регулювання економічного і соціального розвитку на селі та державної підтримки сільгоспвиробника [12]. В Туреччині для рішення проблеми продовольчої безпеки та розвитку виробництва аграрного сектору економіки соціальний захист сільського населення здійснюється шляхом страхування, використання «зеленої картки» та в ряді районів щомісячної субсидії малому бізнесу до 250 доларів [14].

Висновки та перспективи подальших досліджень. Таким чином, розглянувши всі складові продовольчої безпеки, сформулювавши шляхи вирішення забезпечення продовольчої безпеки з різними формами фінансування $з$ урахуванням організаційно-економічного механізму, використовуючи зарубіжний досвід, подальше дослідження може бути спрямоване на розкриття конкретних елементів системи організаційно-економічного механізму забезпечення продовольчої безпеки країни.

Продовольча безпека повинна розглядатись тільки в комплексі 3 національною безпекою країни:

- необхідно розглядати агропродовольчий комплекс як систему, включаючи всі їі сфери, галузі, які забезпечують виробництво сільськогосподарської продукції, безпосередньо сільське господарство, переробні підприємства харчової промисловості, транспортування та зберігання сировини і готової продукції та постачання іï до споживачів;

- повинна бути розроблена програма і план цільового капіталовкладення в соціально-економічний розвиток села та конкретної фінансової підтримки вітчизняного виробника із державного і регіонального бюджетів;

- розподіл кінцевого доходу виробника повинен заохочувати його до зростання обсягу виробництва, тим самим погоджуються та реалізуються економічні інтереси всіх суб'єктів господарювання АПК;

- при побудові організаційно-економічного механізму функціонування і розвитку АПК необхідно використовувати досвід країн $\mathrm{CC}$ в регулюванні розвитку АПК з метою поступового самозабезпечення України основними продуктами вітчизняного виробництва. 


\section{Література}

1. Акмарал Темирова. Обеспечение экономической безопасности внешней торговли в республике Казахстан / Акмарал Темирова, Айгуль Бержанова, Жайна Егизбаева // Актуальні проблеми економіки. - № 9 - 2012. - С. 507-513.

2. Афонцев С. Национальная экономическая безопасность: на пути к экономическому консенсусу / С. Афонцев // Мировая экономика и международные отношения. - № 10. - 2002. - С. 30-31.

3. Басюркіна Н. Й. Пріоритети аграрного розвитку Одеської області в контексті продовольчої безпеки / Басюркіна Н. Й. // Економіка харчової промисловості. - № 3. - 2011. - С. 8-13.

4. Береговой В. К. Проблеми продовольчої безпеки України / Береговой В. К. // Економіка АПК. - № 5. - 2011. - С. 71-78.

5. Бонн Л. Д. Государственное регулирование продовольственного рынка Китая / Продовольственная безопасность КНР и роль государственного регулирования. - М. : РАН, Институт Дальнего Востока. - 2002. - С. 120-149.

6. Закон України «Про основи національної безпеки України» N 964-IV від 19.06.2003. [Електронний ресурс] - Режим доступу: http://zakon4.rada.gov.ua/laws/show/964-15

7. Закон України «Про продовольчу безпеку України» від 22 грудня 2011 року № 4227-VI. [Електронний ресурс] - Режим доступу: http://zakon4.rada.gov.ua/laws/show/4227-6

8. Козак К. Б. Наукові основи дослідження продовольчої безпеки України / К. Б. Козак // Економіка харчової промисловості. № 2. -2014 . - C. 5-10.

9. Ли Чунюй. Зарубежный опыт государственного регулирования аграрного сектора национального хазяйства /Ли Чунюй // Актуальные проблемы экономики. - № 8-2011. - С. 93-99.

10. Маркс К., Энгельс Ф. Соч. Т. 25. Ч. 11. - С. 202-203.

11. Маркс К., Энгельс Ф. Соч. Т. 23. - С. 465.

12. Melicac Vojicic, Leia Ristic, Sasa Obradovic. Rural poverty reduction in the republicof Serbia: a new approach of the jagodinas local selfgovernment / Melicac Vojicic, Leia Ristic, Sasa Obradovic. // Актуальні проблеми економіки. - № 5. - 2012. - C. $339-341$.

13. Немченко В. В. Продовольча безпека: макро- та мікроекономічний аспекти / В. В. Немченко, А. В. Немченко // Економіка харчової промисловості. - № 2. - 2013. - С. 16-18.

14. Celile O. Social security in rural Turkey / Celile O., Dole Koglu, Seta Gun // Актуальні проблеми економіки. - № 1. - 2011. C. 273-283.

15. Стратегія економічного розвитку підприємств харчової промисловості та забезпечення продовольчої безпеки країни : матеріали міжнародної науково-практичної конференції (29-31 жовтня 2012 р.). - Одеса : Фенікс. - 2012. - С. 248.

Стаття надійшла 29.09.2014

Рецензент: Немченко В.В., доктор економічних наук, професор, завідувач кафедри обліку та аудиту Одеської національної академії харчових технологій

Ощепков А.П.

кандидат экономических наук, доцент

кафедра учета и аудита

E-mail: motored@yandex.ru

Магденко C.A.

ассистент

кафедра экономики промышленности

E-mail:maglana@meta.ua

Одесская национальная академия пищевых технологий

ул. Канатная, 112, г. Одесса, Украина, 65039

\section{МЕТОДОЛОГИЧЕСКИЕ ВОПРОСЫ \\ ИССЛЕДОВАНИЯ ПРОДОВОЛЬСТВЕННОЙ БЕЗОПАСНОСТИ В РАМКАХ НАЦИОНАЛЬНОЙ БЕЗОПАСНОСТИ СТРАНЫ}

В работе рассматриваются методологические вопросы исследования продовольственной безопасности в рамках национальной безопасности страны как системы, характеризующейся наличием элементов, структуры и связей, функционирование и развитие которой осуществляется на основе организационно-экономического механизма согласования и реализации экономических интересов всех субъектов деятельности в рамках агропродовольственного комплекса и отдельного предприятия.

Ключевые слова: продовольственная безопасность, национальная безопасность, организационноэкономический механизм, доходы, экономический интерес. 


\author{
Oschepkov 0.P. \\ Ph.D. in Economics, Associate Professor \\ Department of Accounting and Auditing \\ E-mail:motored@yandex.ru \\ Magdenko S.O. \\ Assistant \\ Department of Industrial Economics \\ E-mail:maglana@meta.ua \\ Odessa National Academy of Food Technologies \\ Kanatnaya Street, 112, Odessa, Ukraine, 65039
}

\title{
THE METHODOLOGICAL ISSUES IN THE STADI OF FOOD SECURITY WITHIN THE NATIONAL SECURITY STATE
}

\begin{abstract}
The work is devoted to the study of methodological issues of food security within the country's national security as a system, which is characterized by structural elements, their interconnection and interdependence. The degree of interrelationship and interdependence between them depends on the level of development.

However, the mechanism shown opposite impact on food security components such as demographic security, the consequences of which are characterized by a decrease in births, a decrease in large families because of low solvency and failure to provide adequate food and purchase other goods and services for a normal life. The second factor is related to the significant impact of the aging population, due to a large part of people of retirement age in Ukraine. Economic security is related to insufficient filling of state and local budgets, the development of other industries that use agricultural raw materials.

Thus, the forms and causes of food insecurity and its consequences must be considered at different levels: state, region, city, household, or individual, given the level of solvency of a diverse population, the physical presence of food, quality and pricing on these products.

To further implement measures to overcome deficiencies in food security, it is necessary to build a new organizational and economic mechanism of agri-food sector, the development of which should take into account international experience of countries, especially in Europe, in connection with the signing of association with the EU. Organizational-economic mechanism of APC and individual enterprise is a set of forms and methods of production and work on new technical and technological base, which changes the conditions and nature of work and makes it more attractive for the village, which aims to end performance, meet people quality food and, on this basis, on a long-term profit-sharing which will ensure the implementation and coordination of the interests of workers, the economy and the state. Implementation of the formation of such a model of organizational-economic mechanism is the basis for the inclusion of different types of investments.

Keywords: food security, national security, organizational-economic mechanism, income, economics interest.
\end{abstract}

\section{References}

1. Akmaral Temyrova, Aihul Berzhanova, Zhaina Ehyzbaeva. (2012). Obespechenye ekonomycheskoi bezopasnosty vneshnei torhovly v respublyke Kazakhstan. Aktualni problemy ekonomiky, 9, 507-513.

2. Afontsev S. (2002). Natsyonalnaya ekonomycheskaya bezopasnost: na puty k ekonomycheskomu konsensusu. Mirovaya ekonomyka i mezhdunarodnye otnosheniya, 10, 30-31.

3. Basiurkina N. Y. (2011). Priorytety ahrarnoho rozvytku Odeskoi oblasti v konteksti prodovolchoi bezpeky. Ekonomika kharchovoi promyslovosti, 3, 8-13.

4. Berehovoi V. K. (2011). Problemy prodovolchoi bezpeky Ukrainy. Ekonomika APK, 5, 71-78.

5. Bonn L. D. (2002). Hosudarstvennoe rehulyrovanye prodovolstvennoho rynka Kytaia. Prodovolstvennaia bezopasnost KNR i rol hosudarstvennoho rehulyrovanyia. - M.: RAN, Ynstytut Dalneho Vostoka, 120-149.

6. Zakon Ukrainy «Pro osnovy natsionalnoi bezpeky Ukrainy» № 964-IV vid 19.06.2003. [Elektronnyi resurs]. Rezhym dostupu: http://zakon4.rada.gov.ua/laws/show/964-15

7. Zakon Ukrainy «Pro prodovolchu bezpeku Ukrainy» vid 22 hrudnia 2011 roku № 4227-VI. [Elektronnyi resurs]. Rezhym dostupu: http://zakon4.rada.gov.ua/laws/show/4227-6

8. Kozak K. B. (2014). Naukovi osnovy doslidzhennia prodovolchoi bezpeky Ukrainy. Ekonomika kharchovoi promyslovosti, 2, 5-10.

9. Ly Chuniui. (2011). Zarubezhnyi opyt hosudarstvennoho rehulyrovanyia ahrarnoho sektora natsyonalnoho khoziaistva. Aktualnye problemy ekonomyki, 8, 93-99.

10. Marks K., Enhels F. Soch. Vol. 25, 11, 202-203.

11. Marks K., Enhels F. Soch. Vol. 23, 465.

12. Melicac Vojicic, Leia Ristic, Sasa Obradovic. (2012). Rural poverty reduction in the republic of Serbia: a new approach of the jagodinas local selfgovernment. Aktualni problemy ekonomiky, 5, 339-341.

13. Nemchenko V. V., Nemchenko A. V. (2013). Prodovolcha bezpeka: makro-ta mikroekonomichnyi aspekty. Ekonomika kharchovoi promyslovosti, 2, 16-18.

14. Celile O., Dole Koglu, Seta Gun. (2011). Social security in rural Turkey. Aktualni problemy ekonomiky, 1, $273-283$.

15. Stratehiia ekonomichnoho rozvytku pidpryiemstv kharchovoi promyslovosti ta zabezpechennia prodovolchoi bezpeky krainy: materialy mizhnarodnoi naukovo-praktychnoi konferentsii (29-31 zhovtnia 2012 r.). - Odesa : Feniks, 2012, 248. 